\title{
Prediction of progressive joint damage in patients with rheumatoid arthritis receiving gold or D-penicillamine therapy
}

\author{
P T DAWES, ${ }^{1}$ P D FOWLER,${ }^{1} \mathrm{R}$ JACKSON,${ }^{1} \mathrm{M}$ COLLINS, ${ }^{1} \mathrm{M}$ F SHADFORTH, \\ R STONE, ${ }^{2}$ AND D L SCOTT
}

From the ${ }^{1}$ Staffordshire Rheumatology Centre, Haywood Hospital, Stoke-on-Trent, Staffordshire; and the ${ }^{2}$ Department of Rheumatology, St Bartholomew's Hospital, West Smithfield, London

SUMMARY Seventy two patients with classical or definite rheumatoid arthritis (RA) were randomly allocated to receive gold or D-penicillamine therapy (DPA) in a prospective study designed to evaluate whether it is possible to predict which patients will show radiological progression despite therapy. Forty five patients completed 12 months' treatment. There were no significant demographic or clinical differences between them and the 27 drop outs. Twenty of the 45 patients showed no radiological progression between six and 12 months. These patients had less severe initial radiological damage, lower levels of serum aspartate transaminase (serum AST) and lactic dehydrogenase (LDH), but higher levels of serum cholesterol. Twenty five patients did show progression during the six to 12 month period. This group included all the men with nodules. Of the 43 pretreatment clinical and laboratory variables examined, however, the majority failed to predict whether or not progression would subsequently occur. This included the acute phase response and seropositivity.

Key words: radiological progression, SAARD therapy, serum AST, lactic dehydrogenase, cholesterol, nodules.

Rheumatoid arthritis runs a variable course with frequent exacerbations and remissions. Clinical and laboratory evidence of disease activity relate to progressive joint damage..$^{1-3}$ Although it is accepted that slow acting antirheumatic drugs (SAARDs) improve laboratory and clinical features of disease, it is not accepted that they may decrease the rate of radiological progression. ${ }^{4}$ We have previously demonstrated that a group of patients with RA receiving SAARDs showed progressive radiological damage throughout the first 12 months of therapy but that a subgroup who achieved a good response to therapy at six months, maintained at 12 months, had less deterioration. ${ }^{6} 7$ SAARD therapy is potentially toxic, so the risk-benefit ratio has to be estimated by the clinician for each individual patient. If, by definition of prognostic features, we

Accepted for publication 21 April 1986.

Correspondence to Dr P T Dawes, Staffordshire Rheumatology Centre, Haywood Hospital, High Lane, Burslem, Stoke-on-Trent, Staffordshire ST6 7AG. could identify patients whose disease is most likely to become well controlled we could improve this ratio. Furthermore, advanced recognition of poor prognostic features would indicate patients in whom more aggressive ${ }^{8}$ or combination therapy ${ }^{9}$ should be considered initially.

We have studied patients with active RA requiring gold or DPA therapy and grouped those completing 12 months' treatment according to the radiological progression during the six to 12 month period. Pretreatment characteristics of the groups have been compared in an attempt to identify any predictors of radiological response.

\section{Patients and methods}

PATIENTS

Seventy two patients with classical or definite RA (American Rheumatism Association (ARA) criteria) attending the Staffordshire Rheumatology Centre were randomly allocated to receive treatment with 
gold or DPA. Exclusion criteria included administration of a SAARD within the previous three months and pregnancy. Admission criteria were failure to respond to non-steroidal anti-inflammatory drugs or antimalarial drugs and/or progression of disease as shown by increasing clinical, laboratory, or radiological features of disease. Mandatory entry criteria were $(a)$ more than six painful joints and $(b)$ erythrocyte sedimentation rate (ESR) $>30 \mathrm{~mm} / 1 \mathrm{st}$ $\mathrm{h}$ or $\mathrm{C}$ reactive protein $>20 \mathrm{mg} / \mathrm{l}$, or both. A standard dosage regimen for gold and DPA was used. Gold was started at $50 \mathrm{mg} /$ week for 20 weeks and then $50 \mathrm{mg} / 2$ weeks; DPA was started at 250 $\mathrm{mg} /$ day for one month, then $375 \mathrm{mg} /$ day, and increased by not more than $125 \mathrm{mg} /$ day each month thereafter according to response to a maximum of $750 \mathrm{mg} /$ day. All the patients could have completed 12 months' therapy and 45 did so. The reason for withdrawal in the 27 drop outs is shown in Table 1. They appeared to have more severe disease initially, though only the ESR reached significance (Table 2).

\section{CLINICAL MEASURES}

Details recorded at initial examination included length of history, presence of nodules, and ARA criteria. Disease activity was assessed by clinical

Table 1 Reason for withdrawal in the 27 patients not completing 12 months' therapy

\begin{tabular}{lll}
\hline & Gold & D-Penicillamine \\
\hline Adverse reaction & 13 & 5 \\
Deteriorating disease & 1 & 3 \\
Non-compliance & 2 & 3 \\
\hline
\end{tabular}

Table 2 Comparison of pretreatment results for patients completing 12 months' therapy and withdrawals

\begin{tabular}{|c|c|c|c|}
\hline & $\begin{array}{l}12 \text { Month } \\
\text { Completers }\end{array}$ & $\begin{array}{l}\text { Non- } \\
\text { completers }\end{array}$ & p Value \\
\hline No & 45 & 27 & \\
\hline Mean age (years) & $54 \cdot 4$ & $56 \cdot 6$ & $0 \cdot 19$ \\
\hline $\begin{array}{l}\text { No of men } \\
\text { Mean length of history }\end{array}$ & $24(53 \%)$ & $12(44 \%)$ & 0.62 \\
\hline (months) & $74 \cdot 2$ & 81 & $0 \cdot 29$ \\
\hline No seropositive $(1 / 80)$ & $28(62 \%)$ & $21(77 \%)$ & $0 \cdot 26$ \\
\hline $\begin{array}{l}\text { No with nodules } \\
\text { Median hand and feet } x \text { ray }\end{array}$ & $16(35 \%)$ & $11(40 \%)$ & $0 \cdot 85$ \\
\hline score (Larsen) & 64 & 64 & 0.07 \\
\hline $\begin{array}{l}\text { Median Ritchie index } \\
\text { Median morning stiffness }\end{array}$ & 16 & 18 & $0 \cdot 21$ \\
\hline $\begin{array}{l}\text { (min) } \\
\text { Mean } C \text { reactive protein }\end{array}$ & 120 & 170 & $0 \cdot 31$ \\
\hline (mg/l) & $70 \cdot 1$ & $88 \cdot 3$ & $0 \cdot 06$ \\
\hline Mean ESR (mm/1st h) & $67 \cdot 8$ & $81 \cdot 1$ & $0 \cdot 03$ \\
\hline
\end{tabular}

metrologists at the start of therapy. Functiona assessment was on the Steinbrocker 1 to 5 scale. Thes number of painful joints was recorded (maximum 28 ), and the tenderness of each joint group was? measured by the method of Ritchie with a maximume possible score of 84 . A limited Ritchie index음 confined to the proximal interphalangeal (PIP) metacarpophalangeal (MCP), wrist, and metatar $\triangle$ sophalangeal (MTP) joints was recorded with w maximum possible score of 24 . Visual analogue painscore (VAS) was recorded on a $10 \mathrm{~cm}$ horizontal line? and recorded in millimetres from no pain. Morning stiffness was recorded in minutes to a maximum of $720 \mathrm{~min}$. Grip strength was measured by the standard technique. Synovial thickening was estimated for each finger PIP joint and thumb IP joint on a four point scale (maximum score 30 ).

\section{LABORATORY MEASUREMENTS}

Morning samples were taken the day treatmen started. Routine haematology, biochemistry (SMAC), ESR (Westergren), C reactive proteino (CRP), and antinuclear antibody estimations were足 carried out. Rheumatoid factor was assessed by standard agglutination test (Ortho RA test). IgGR and IgM rheumatoid factor (enzyme linked if $\overrightarrow{0}$ munosorbent assay (ELISA)), immunoglobuli and $\alpha_{1}$ antitrypsin measurements were performe on sera stored at $-70^{\circ} \mathrm{C}$.

\section{RADIOLOGICAL MEASUREMENTS}

Hand and feet radiographs were taken beforê treatment and at six and 12 months. They were readp 'blind' by a single observer and scored using the $\overrightarrow{0}$ standard radiographs of Larsen et al. ${ }^{10}$ Patients were subgrouped into two according to the change in the Larsen score during the six to 12 month period? group I having a maximum score increase of one group II having a score increase of more than one?

\section{STATISTICS}

Analysis of results between groups was by analysis of variance when the variables were normally distributed. Between group analysis for variables not normally distributed was by the Mann-Whitney $\mathrm{U}$ test. Comparison between groups was also made by the $\chi^{2}$ test and Fisher's exact test when approprif ate. As 43 variables were compared there is a risk of a type I error and therefore only a $p$ value of les than 0.02 was regarded as significant.

\section{Results}

RADIOLOGICAL

Patients were divided into two groups as described 0 Group I patients had a significantly lower Larser? 
Table 3 The Larsen index score for group I and II patients at 0, 6, and 12 months and the mean change

\begin{tabular}{|c|c|c|c|c|c|}
\hline & Group I $(n=20)$ & $\begin{array}{l}95 \% \text { Confidence } \\
\text { limits }\end{array}$ & Group II $(n=25)$ & $\begin{array}{l}95 \% \text { Confidence } \\
\text { limits }\end{array}$ & p Value \\
\hline Mean Larsen index ( 0 months) & $49 \cdot 1$ & $8 \cdot 1$ & $62 \cdot 8$ & $8 \cdot 5$ & $0 \cdot 01$ \\
\hline Mean Larsen index ( 6 months) & 54 & $8 \cdot 8$ & $67 \cdot 4$ & $9 \cdot 1$ & 0.02 \\
\hline Mean change $(6-0)$ & $+4 \cdot 9$ & $1 \cdot 2$ & $+4 \cdot 6$ & 1.4 & 0.7 \\
\hline Mean Larsen index (12 months) & 53.6 & $8 \cdot 9$ & $71 \cdot 6$ & $9 \cdot 6$ & 0.004 \\
\hline Mean change $(12-6)$ & -0.4 & 0.6 & $+4 \cdot 2$ & $1 \cdot 0$ & 0.009 \\
\hline
\end{tabular}

Table 4 Comparison of pretreatment clinical variables

\begin{tabular}{|c|c|c|c|c|c|}
\hline & Group I $(n=20)$ & $\begin{array}{l}95 \% \text { Confidence } \\
\text { limits }\end{array}$ & Group II $(n=25)$ & $\begin{array}{l}95 \% \text { Confidence } \\
\text { limits }\end{array}$ & p Value \\
\hline Gold:DPA & $9: 11$ & & $12: 13$ & & \\
\hline Mean age (years) & $52 \cdot 3$ & $5 \cdot 4$ & $56 \cdot 2$ & 3.8 & $0 \cdot 24$ \\
\hline Mean length of history (months) & 62 & $20 \cdot 6$ & 84 & $21 \cdot 2$ & 0.09 \\
\hline No of men & 8 & & 16 & & $0 \cdot 14$ \\
\hline No with nodules & 4 & & 12 & & 0.045 \\
\hline Mean ARA criteria & 6.9 & 0.33 & $7 \cdot 1$ & $0 \cdot 27$ & $0 \cdot 16$ \\
\hline Mean Steinbrocker scale & $2 \cdot 15$ & $0 \cdot 29$ & $2 \cdot 0$ & $0 \cdot 3$ & $0 \cdot 3$ \\
\hline Mean No of painful joints & $9 \cdot 7$ & $2 \cdot 1$ & $11 \cdot 0$ & $2 \cdot 4$ & 0.42 \\
\hline Mean VAS pain score (mm) & $57 \cdot 4$ & $9 \cdot 4$ & 56.4 & $9 \cdot 8$ & 0.89 \\
\hline Mean morning stiffness (min) & 161 & 89 & 81 & 27 & $0 \cdot 07$ \\
\hline Mean grip strength $(\mathrm{mmHg})$ & 125 & 25 & 123 & 21 & 0.92 \\
\hline $\begin{array}{l}\text { Mean Ritchie articular index } \\
\text { Mean Ritchie index }\end{array}$ & $14 \cdot 5$ & $3 \cdot 5$ & $17 \cdot 2$ & $4 \cdot 1$ & $0 \cdot 33$ \\
\hline (hands and feet only) & $5 \cdot 7$ & $1 \cdot 7$ & $6 \cdot 2$ & $1 \cdot 3$ & 0.69 \\
\hline Mean PIP synovitis score & 9.4 & $2 \cdot 5$ & $11 \cdot 2$ & $3 \cdot 1$ & 0.4 \\
\hline
\end{tabular}

Table 5 Comparison of pretreatment variables

\begin{tabular}{|c|c|c|c|c|c|}
\hline & Group I $(n=20)$ & $\begin{array}{l}95 \% \text { Confidence } \\
\text { limits }\end{array}$ & Group II $(n=25)$ & $\begin{array}{l}95 \% \text { Confidence } \\
\text { limits }\end{array}$ & p Value \\
\hline \multicolumn{6}{|l|}{ Mean values } \\
\hline Haemoglobin $(\mathrm{g} / \mathrm{dl})^{*}$ & $11 \cdot 4$ & $0 \cdot 61$ & $11 \cdot 5$ & 0.51 & 0.91 \\
\hline Platelets $\times 10^{-9} / 1$ & 532 & 53 & 505 & 53 & 0.49 \\
\hline $\operatorname{ESR}(\mathrm{mm} / 1 \mathrm{st} \mathrm{h})$ & 62 & 11 & 73 & 10 & $0 \cdot 18$ \\
\hline $\mathrm{C}$ reactive protein $(\mathrm{mg} / \mathrm{l})$ & 62 & 12 & 77 & 17 & $0 \cdot 19$ \\
\hline$\alpha_{1}$ Antitrypsin (U/I) & 214 & 27 & 185 & 19 & 0.08 \\
\hline Albumin $(\mathrm{g} / \mathrm{l})$ & $39 \cdot 1$ & $1 \cdot 1$ & $37 \cdot 6$ & $1 \cdot 1$ & 0.08 \\
\hline Globulin $(\mathrm{g} / \mathrm{l})$ & $37 \cdot 7$ & $2 \cdot 7$ & $41 \cdot 0$ & $2 \cdot 4$ & 0.08 \\
\hline Alkaline phosphatase (U/l) & 118 & 14 & 127 & 17 & 0.47 \\
\hline Serum AST (U/l) & $11 \cdot 7$ & $1 \cdot 7$ & $15 \cdot 3$ & 1.9 & 0.01 \\
\hline Lactic dehydrogenase (U/l) & 192 & 15 & 235 & 23 & 0.005 \\
\hline Cholesterol (mmoll) & $5 \cdot 1$ & 0.4 & 4.5 & 0.23 & 0.008 \\
\hline IgM rheumatoid factor (ELISA U/1) & 0.47 & $0 \cdot 19$ & 0.45 & $0 \cdot 16$ & 0.49 \\
\hline IgG rheumatoid factor (ELISA, U/I) & 0.66 & $0 \cdot 17$ & 0.61 & $0 \cdot 12$ & 0.6 \\
\hline \multicolumn{6}{|l|}{ No of patients } \\
\hline Seropositive (Titre $\geqslant 1 / 80$ ) & 12 & & 16 & & 0.97 \\
\hline ANF positive $\dagger$ (Titre $\geqslant 1 / 32$ ) & 8 & & 8 & & 0.29 \\
\hline
\end{tabular}

\footnotetext{
* SI conversion: haemoglobin $\mathrm{g} / \mathrm{dl} \times 10=\mathrm{g} /$.
}

$\dagger \mathrm{ANF}=$ antinuclear factor.

Total differential white cell count (neutrophils, lymphocytes, monocytes, eosinophils), blood creatinine, urea, $\gamma$-glutamyltransferase, conjugated and unconjugated bilirubin and uric acid, IgA, IgM, and IgG were also analysed and showed minimal differences between the two groups - the lowest $p$ value being $>0 \cdot 21$. The median RA factor titre $(1 / 160)$ and ANF titre $(1 / 80)$ was the same in each group. 
score before the start of treatment (Table 3). Both groups showed progressive changes during the first six months of therapy, and the rate of change was similar. During the second six months no significant deterioration occurred in group I and the mean score in group II increased by $\mathbf{4 \cdot 2}$.

\section{CLINICAL}

The number of patients having gold and DPA was similar in the two groups. Of the 13 clinical variables analysed (Table 4) on subgroup analysis, one feature, men with nodules, showed a significant relation with the $x$ ray progression $(p=0 \cdot 017)$.

\section{LA B ORATORY}

Comparison between the groups was made for all the haematological, biochemical, acute phase response, and immunological features. These are shown in Table 5 . The only differences established were significantly higher mean levels of serum AST and LDH in group II and cholesterol in group I. In particular, there was no relation between outcome and $(a)$ seropositivity by the titre and the ELISA technique; $(b)$ levels of immunoglobulin; $(c)$ clinical variables such as morning stiffness and the degree of joint swelling and pain; and $(d)$ the initial acute phase response.

\section{Discussion}

There is disagreement about the effect of SAARD therapy on the rate of radiological progression. ${ }^{4} 511$ $\mathrm{RA}$ is not a static disease, 12 and the different opinions may be because SAARDs are effective only in certain phases. Furthermore, RA is a heterogeneous disease, in which subgroups may show differing responses. One feature may be the presence of rheumatoid factor, ${ }^{13}$ which has been related to the pattern of radiological progression. ${ }^{14} 15$ Patients with low levels of ESR and CRP, irrespective of therapy, have less radiological progression. ${ }^{3}$

All the patients in our study had failed to respond to various treatments and were showing progression of disease so that, by definition, patients with early disease or minimal radiological damage were unlikely to be included. A high proportion did not continue treatment and so did not have the appropriate 12 month radiological examination. Their progress could thus not be compared with those who completed.

All our patients had high ESR or CRP levels, or both, at the outset of the study, and it was therefore expected that without adequate disease control they would continue to show progression of the radiological changes. Despite the problem in scoring routine $x$ rays $^{16}$ we were able to define two groups $\underline{\underline{V}}$. -those who did and those who did not show progression in the six to 12 month period of $\overrightarrow{\vec{D}}$ treatment.

Previous studies have shown that high seropositivity and nodule formation are bad prognostic

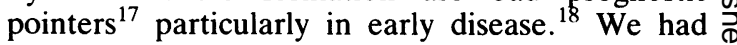
hoped to recognise other prognostic features, par- $\Omega$ ticularly in relation to progression of radiological is changes. We found no relation with rheumatoid $\overrightarrow{0}$ factor, but all men with nodules continued to show radiological deterioration. (There were no men with $\vec{\omega}$ nodules in group I compared with eight in group II.) We did identify higher group mean levels of $\mathrm{LDH}$, ? serum AST, or initial $x$ ray score and lower serum of cholesterol as poor prognostic features. The higher levels of serum AST are probably due to the hepatic dysfunction in active $\mathrm{RA},{ }^{19}$ though none of our $\mathrm{B}$ patients had abnormal levels. Although raised levels $\circ$ of $\mathrm{LDH}$ have not been previously noted in RA, there was a striking difference in means between the $z$ two groups. Seven of the patients in group II had levels above the normal, whereas there were none in group I. This could relate to hepatic dysfunction, or possibly represent an enzyme release from poly morphs within joints. ${ }^{20}$

Joint damage in RA as measured by radiologicas changes has two causes: continuing cartilage damage by inflammatory pannus and secondary damage by use of joints with incongruous or misaligned articulating surfaces following inflammatory damage. Suppressive drugs will control the inflammatory aspects of the disease, so that it is not surprising that they have been shown to be more effective when used early. ${ }^{21}$ Our group I patients had a significantly lower initial $x$ ray damage score.

It would be of great clinical and economic value if we could predict the likely outcome of SAARD therapy in individual patients. Some important factors such as immune complexes ${ }^{22}$ and cellular immune response ${ }^{23}$ were not considered in this study and facilities were not available for genetic studies. Although we have recognised that certain particular high or low group mean levels indicate poor prognosis, these are insufficiently precise to apply to individual patients, though certain pointers such as men with nodules, high levels of LDH and serum AST with low cholesterol indicate the need for early aggressive therapy.

Our study does not imply the impossibility of identifying precise prognosticators but indicates the difficulty in separating the inflammatory and mechanical features of the disease. A similar study limited to patients with active inflammatory disease but minimal though definite radiological damage would have much greater likelihood of success. 


\section{References}

1 Sharp J T, Lidsky M D, Duff J. Clinical response during gold therapy for rheumatoid arthritis. Changes in synovitis, radiologically detectable erosive lesions, serum proteins and serologic abnormalities. Arthritis Rheum 1982; 25: 540-9.

2 Sjoblom K G, Saxne T, Petterson H, Wollheim F A. Factors related to the progression of joint destruction in rheumatoid arthritis. Scand J Rheumatol 1984; 1: 21-7.

3 Amos R S, Constable T J, Crockson R A, Crockson A P, McConkey B. Rheumatoid arthritis: a relation of serum Creactive protein and erythrocyte sedimentation rates to radiographic changes. $\mathrm{Br}$ Med J 1977; i: 195-7.

4 Iannauzzi L, Dawson N, Zein N, Kusher I. Does any therapy slow radiographic deterioration in rheumatoid arthritis. $N$ Engl J Med 1983; 309: 1023-8.

5 Kirwan J R, Currey H L F. Rheumatoid arthritis-disease modifying anti-rheumatic drugs. Clin Rheum Dis 1983; 9: $581-600$.

6 Scott D L, Dawes P T, Fowler P D, Grindulis K A, Shadforth M F, Bacon P A. Anti-rheumatic drugs and joint damage in rheumatoid arthritis. $Q J$ Med 1985; 54: 49-59.

7 Dawes P T, Fowler P D, Clarke S, Fisher J, Lawton A, Shadforth M F. Rheumatoid arthritis: treatment which controls the $\mathrm{C}$-reactive protein and erythrocyte sedimentation rate reduces radiological progression. Br J Rheumatol 1986; 25: 44-9.

8 Co-operating Clinics Committee of the American Rheumatism Association. A controlled trial of cyclophosphamide in rheumatoid arthritis. N Engl J Med 1970; 283: 883-9.

9 McCarty D J, Carrera G F. Intractable rheumatoid arthritis: treatment with combined cyclophosphamide, azathioprine and hydroxychloroquine. JAMA 1982; 248: 1718-23.

10 Larsen A, Dale K, Eck M. Radiographic evaluation of rheumatoid arthritis and related conditions by standard reference films. Acta Radiol [Diagn] (Stockh) 1977; 18: 481-91.

11 Pullar T, Hunter J A, Capell H A. Does second-line therapy affect the radiological progression of rheumatoid arthritis? Ann Rheum Dis 1984; 43: 18-23.

12 Panayi G S. Viewpoint: Does rheumatoid arthritis have a clinicopathological spectrum similar to that of leprosy? Ann Rheum Dis 1982; 41: 102-3.

13 Bland J H, Brown E W. Seronegative and seropositive rheumatoid arthritis: clinical, radiological and biochemical differences. Ann Intern Med 1964: 60: 88-94.

14 Burns T, Calin A. The hand radiograph as a diagnostic discriminant between seropositive and seronegative 'rheumatoid arthritis': a controlled study. Ann Rheum Dis 1983: 42: 605-12.

15 Withrington $\mathrm{R} \mathrm{H}$, Seifert $\mathrm{M} \mathrm{H}$. Predominant wrist disease in rheumatoid arthritis associated with high concentration of $\operatorname{IgA}$ rheumatoid factor. $\mathrm{Br}$ Med J 1985; 291: 1388.

16 Gofton J P. Problems associated with measurement of radiological progression of disease in rheumatoid arthritis. J Rheumatol 1983; 10: 177-9.

17 Dudley-Hart F. Presentation of rheumatoid arthritis and its relation to prognosis. $\mathrm{Br}$ Med J 1977; ii: 621-4.

18 Masi A T, Maldaldo-Cocco J A, Kaplan S B. Prospective study of the early course of rheumatoid arthritis in young adults: comparison of patients with and without rheumatoid factor positivity at entry and identification of variables correlating with outcome. Semin Arthritis Rheum 1976; 5: 299-326.

19 Fernandes L, Sullivan S, McFarlane I G, et al. Studies on the frequency and pathogenesis of liver involvement in rheumatoid arthritis. Ann Rheum Dis 1979; 38: 501-6.

20 Thompson $\mathrm{P} \mathrm{W}$, Jones D D, Currey H L F. Cytidine deaminase: a measure of synovial inflammation? $\mathrm{Br} J$ Rheumatol 1985; 24: 203-4.

21 Luukkainen $R$, Isomäki $H$, Kajander $A$. Effect of gold treatment on the progression of erosions in rheumatoid arthritis patients. Better results with early treatment. Scand J Rheumatol 1977; 6: 123-7.

22 Ochi T, Yonemasu K, Iwase R, Sasaki T, Tsuyama K, Ono K. Serum C1q levels as a prognostic guide to articular erosions in patients with rheumatoid arthritis. Arthritis Rheum 1984; 27: 883-7.

23 Barada F A, O'Brien W, Horwitz D A. Defective monocyte cytotoxicity in rheumatoid arthritis Arthritis Rheum 1982; 25: $10-6$. 